\title{
Motivations Among Special Education Students and their Parents for Switching to an Online School: Survey Responses and Emergent Themes
}

\author{
DeLaina Tonks \\ Mountain Heights Academy \\ Royce Kimmons and Stacie L. Mason \\ Brigham Young University
}

\begin{abstract}
Research focusing on the experiences of special education students in online $\mathrm{K}-12$ schools is scant despite growing numbers of enrollments. This study utilized an emailed survey to understand the motivations and experiences of a group of special education students $(n=30)$ and their parents $(n$ =29) while enrolled in an online K-12 school in the U.S. Responses indicated that the three most compelling reasons for choosing the school were flexibility, previous poor fit, and teacher availability. Qualitative analysis of open-ended responses produced two major themes-prior experiences and affordances of the learning environment - with sub-themes related to bullying, personnel, academics, disabilities and accommodations, health considerations, lack of support, self-determination, and the where, when, and how of online learning. These findings may help policy makers enact policies and online educators adapt their approach to better meet the needs of $\mathrm{K}-12$ students with special needs.
\end{abstract}

Keywords: K-12, special education, virtual classrooms, school choice

Tonks, D., Kimmons, R., \& Mason, S.L. (2021). Motivations among special education students and their parents for switching to an online school: Survey responses and emergent themes. Online Learning, 25(2), 171-189. https://doi.org/10.24059/olj.v25i2.2141

\section{Motivations Among Special Education Students and Their Parents for Switching to an Online School: Survey Responses and Emergent Themes}

In the United States, special education is governed primarily by federal laws, which include several landmark cases positioned to ensure equitable access to education for all students. Special education became a recognized civil right for children with disabilities near the end of the 20th century when Congress enacted legislation known as the Education for All Handicapped Children Act on November 29, 1975. This legislation ensured that students with disabilities occupied a 
specified seat in secondary and post-secondary education in the United States and today is referred to as the Individuals with Disabilities Education Improvement Act (IDEIA) (20 U.S.C. $§ 1400$, 2004). All public schools are now required to provide a free appropriate public education, a standard commonly referred to as FAPE, to all of their students (20 U.S.C. § 1400, 2004). As such, public online schools are bound by the same laws and rules as their public brick-and-mortar district and charter school counterparts: to meet the needs of all students.

Online, or cyber, schooling has expanded rapidly over the past 20 years (Beck et al., 2014; Clifford, 2018). The 2020 Keeping Pace Snapshot estimated enrollments of 375,000 full-time and several million part-time online students in 2018-2019 (Digital Learning Collaborative, 2020). The number of students with special needs attending online schools has also increased (Beck et al., 2014; Molnar, 2019). Yet, little research has been done to understand the experiences of special education students in online schools (Barbour \& Reeves, 2009; Burdette et al., 2013; Clifford, 2018). Studies on how to meet the needs of lower-performing students and students with disabilities have lagged to the point that researchers have issued various direct calls to determine the quality of their online learning experiences (Cavanaugh et al., 2009; Ferdig \& Kennedy, 2013; Vasquez \& Serianni, 2012). The current study is an answer to this call.

\section{Review of Relevant Literature}

The recent expansion of online schooling may be attributed to various benefits and to the changing dynamics of modern educational offerings (Barbour \& Reeves, 2009; Cavanaugh, Gillan et al., 2004; Hassel et al., 2001). Students and parents have indicated that they chose online schools both to flee negative environments and to take advantage of online schools' flexibility and convenience (Ahn, 2011; Beck et al., 2014; Hasler-Waters et al., 2014; Macy et al., 2018). State directors of special education have likewise indicated that flexibility was a driving factor behind offering online education (Burdette et al., 2013).

As of the 2017-2018 school year, "the proportion of special education students in virtual schools with data was higher than the national average" (Molnar et al., 2019, p.8). This finding represents an increase in enrollments since the 2015 report, which stated that special education students were enrolled in online schools at lower rates than the national average (Molnar et al., 2015). In both reports, the statistics present only part of the story, as parents and school administrators apply designations inconsistently and some schools and states do not report data about students with disabilities (Beck et al., 2014; Betts et al., 2013; Clifford, 2018; Molnar et al., 2015; Molnar et al., 2019). Previous studies (Beck et al., 2014; Fernandez et al., 2016; Woodworth et al., 2015), our own personal experiences with K-12 online schools, and our interactions with colleagues in other states indicate that some online schools have enrolled students with disabilities at higher rates than state averages.

In some ways, online schools may be better suited than traditional schools to meet special needs (Basham et al., 2015; Beck et al., 2014). Students can learn at their own pace, reviewing material as needed. Teachers can tutor small groups or individuals, achieving Bloom's 2 sigma ideal (1984) of discovering group instructional methods that provide results as effective as oneon-one tutoring. When instructional content is both online and open, teachers can adapt learning materials to meet diverse needs, differentiate instruction, and align instruction with standards (de los Arcos et al., 2016; Geith \& Vignare, 2008). These best practices are useful for students generally but may be especially helpful for students with disabilities. 
However, for online schools to realize these benefits, teachers must be prepared to provide effective online instruction for their students with disabilities. Teaching online requires different competencies from traditional teaching (Ahn, 2011; Pulham \& Graham, 2018), and few training programs prepare teachers to teach online (Basham et al., 2015). Though teacher training programs provide special education training, many states face shortages of qualified special education teachers (Mason-Williams et al., 2019; Peyton et al., 2020) and many general education teachers lack understanding of how to meet students' special needs, or their responsibility to do so (Cavendish et al., 2020; Kozleski, 2020; Rice \& Carter, 2015).

Furthermore, instruction should be designed for accessibility, yet those designing online instruction may not understand principles of universal design (Betts et al., 2013; Macy et al., 2018; Singleton et al., 2019). Students with disabilities may face multiple barriers to accessibility, such as text complexity, visual components, and navigability (Clifford, 2018). In an analysis of websites for K-12 special education cooperatives serving students aged 3 to 21, Baule (2020) found that only $25 \%$ of websites analyzed met basic levels of accessibility compliance, and a recent nationwide study of K-12 school websites found that most school websites fail accessibility checks with a very high number of basic errors, such as insufficient contrast between text and backgrounds, lack of alternative text on images, missing form labels, etc. (Kimmons \& Smith, 2019).

Since they are physically separated from their teachers, online students with special needs require especially strong support at home (Carnahan \& Fulton, 2013; Ortiz et al., 2017; Schuck \& Lambert, 2020). Regardless of a student's ability, online schooling requires parents and family to invest significant time; parents of students of disabilities have reported spending one to seven hours per day helping their child with online school (Clifford, 2018). In some cases, parents may act as the primary instructor while the teacher takes the support role (Barbour, 2009; Carnahan \& Fulton, 2013; Ortiz et al., 2017; Rice \& Carter, 2015). While parents have the advantage of knowing their child better than the teacher does, and some parents may welcome the opportunity to be more involved in their children's schooling (Sorensen, 2019), most parents lack the training and resources to provide the support and instruction that online schooling may require. Despite these challenges, researchers have still found that parents of special education students preferred their children's online schools to previous brick-and-mortar schools (Beck et al., 2014; Clifford, 2018).

Teachers have likewise indicated that teaching online is challenging, due to large caseloads, a lack of known best practices, lack of parental support, and feelings of being disconnected from their students and from other teachers (Clifford, 2018; Hawkins et al., 2012; Rice \& Carter, 2016; Schuck \& Lambert, 2020). Online special education teachers have indicated that they see their role "as more 'facilitators of' than 'designers of' instruction" (Clifford, 2018, p. 39), because most virtual schools use pre-packaged curricula (Crouse et al., 2016; Greer et al., 2014; Rice \& Carter, 2016). Online special education teachers have reported that they felt proficient in their teaching roles though they lacked formal training to teach students with disabilities online (Crouse et al., 2016).

Studies suggest that student achievement in online schools has been lower than in brickand-mortar schools (Clifford, 2018). Barbour et al. (2017) found that online students performed at lower levels than their brick-and-mortar peers. Woodworth et al. (2015) similarly reported that online students showed less improvement in reading and math than students in brick-and-mortar schools. Fernandez et al. (2016) reported that among participants in the study, students with special 
health care needs (as identified through the Child with Special Health Care Needs Screener) had earned significantly lower grades in online schools than in brick-and-mortar schools. Molnar et al. (2019) reported that only $48 \%$ of reporting virtual schools had received acceptable ESSA (Every Student Succeeds Act) performance ratings in 2017-2018, and 56\% of virtual schools had not received ratings.

Studies of student perceptions show mixed experiences with online schools (Clifford, 2018). In a study by Harvey et al. (2014), most virtual school students said they liked online classes and were satisfied with the amount of interaction with teachers but dissatisfied with social and extracurricular opportunities. Oliver et al. (2009) reported that in Likert-scale responses, most virtual school students expressed satisfaction with their teachers' knowledge, training, and instruction, but in open-ended responses, many students indicated that they felt disconnected from teachers and dissatisfied with instruction.

Little research has been done to understand the experiences of special education students in online schools (Barbour \& Reeves, 2009; Burdette et al., 2013). In the few existing studies, students with special needs, like the larger student population, have reported mixed experiences with online schools (Clifford, 2018). Woodfine et al. (2008) reported that students with dyslexia in online synchronous classes reported feeling embarrassed and anxious, falling behind, avoiding tasks, and being excluded from activities due to their disability and accompanying low confidence. In contrast, Beck et al. (2014) found that special education students reported higher satisfaction with online school and lower satisfaction with prior schools than did their peers.

More research is needed to understand special education students' motivations for and experiences while attending online schools. To this end, we surveyed a group of special education students enrolled in a public, online school in the western U.S. and their parents, to better understand students' motivations for attending the school and their experiences while attending it. We used both descriptive statistics and qualitative methods to analyze responses.

\section{Methods}

The guiding questions of this study were: (a) Why did students with specific special education needs (and their parents) choose this online school? and (b) How or why is it working for them? We utilized a survey methodology with both Likert-scale type and open-ended questions to gather data from both groups for descriptive and qualitative analysis.

\section{Context}

The targeted online school opened in 2009 with 127 ninth graders and seven faculty and staff. Of those initially enrolled students, only 3.9\% had special education classifications. Enrollment at the school steadily grew as new grades were added, and by the 2016-2017 school year, it had grown to 525 students between grades $8-12,15.4 \%$ of whom had special education classifications. This is higher than the Utah state average for special education students, which has hovered between 11\% and 13\% since the school opened in 2009 (National Center for Education Statistics, 2017).

In previous school surveys, students indicated that they had enrolled because (1) their previous educational setting was not working for them, (2) they valued the flexibility of fitting school in around their own schedule, and (3) they enjoyed the interactions they had with their teachers (Swinton, 2017, p. 5). Content is available asynchronously and can be accessed from any 
device so students can work anywhere and anytime. The school also operates on a curricular model that emphasizes the use of open educational resources (OER) and hires teachers with instructional design skills to create, adapt, and remix these materials to meet student needs.

All coursework is organized into weekly folders and is due at 6:00 p.m. each Friday. General education teachers are available four hours a day during office hours, and by appointment, via chat, video conference, phone, or email to assist students as needed. During the other four school hours per day, teachers contact parents, grade student work, analyze data to inform instruction, and reach out specifically to struggling students to motivate them. In order to be responsive to parents and students, all administrators, faculty, and staff adhere to the school communication policy of responding to all communications within 24 hours (Employee Handbook and Policy Guide, 2017). In the event a teacher is not readily available to assist a student, a 24hour tutoring service is also available. Students can access a certified educator or instructional paraeducator to tutor them in math, science, or English through a single button click. If a student is struggling significantly, they may be required to work with a certified tutor or instructional paraeducator.

\section{Participants}

Given the scope of our research question, we focused our study on returning families with full-time 8-12 grade special education students who had an existing IEP prior to attending the school, to ensure the parents and students have enough experience with this particular special education program to answer the survey questions. Students on a 504 plan, specific to students with disabilities who need accommodations but do not qualify for special education services, were not included because 504 plans are governed by a different set of laws. Student participants represented a $60 / 40 \%$ split of male-to-female, which, along with racial/ethnic composition of the sample, generally reflected the overall population of students with disabilities at the school (Table $1)$.

\section{Table 1}

Demographics of Student Survey Participants

\begin{tabular}{lccc} 
Sub-category & $\begin{array}{c}\text { Student } \\
\text { Participants }\end{array}$ & $\begin{array}{c}\text { Participant } \\
\text { Representation }\end{array}$ & $\begin{array}{c}\text { School SWD } \\
\text { Representation * }\end{array}$ \\
\hline Male & 18 & $60 \%$ & $56 \%$ \\
Female & 12 & $40 \%$ & $44 \%$ \\
White & 24 & $80 \%$ & $96 \%$ \\
Hispanic or Latino & 3 & $10 \%$ & $12.5 \%$ \\
American Indian or Alaskan Native & 2 & $6.7 \%$ & $0.5 \%$ \\
Hawaiian/Pacific Islander & 1 & $3.3 \%$ & $0.3 \%$ \\
\hline
\end{tabular}

* Race/ethnicity percentages may exceed $100 \%$ because some students identify as multiracial. 
Given the stark rise in enrollment of students classified with disabilities at the school, further understanding of these classifications is warranted. There are 13 special education student codes or classifications used to identify specific disabilities: autism (AU), emotional disturbance (BD), speech/language impairment (CD), deaf/blindness (DB), developmental delay (DD), hearing impairment/deafness (HI), intellectual disability (ID), multiple disabilities (MD), other health impairment $(\mathrm{OH})$, orthopedic impairment $(\mathrm{OI})$, specific learning disability $(\mathrm{SL})$, traumatic brain injury (TB), visual impairment (VI). At this school, three of the classification categories, (1) autism, (2) specific learning disability, and (3) other health impairment, currently represent $93.7 \%$ of students with disabilities and $14.1 \%$ of the student population generally (cf., Fig. 1). When the percentage of students on an Individualized Education Program (IEP) at this online school is viewed through the lens of the distribution of students in the separate classifications, the difference between the school, state, and national averages becomes even more disparate, showing uncommonly high percentages of students classified with autism $(+8.6 \%$ above state and $+7.2 \%$ above national averages), specific learning disabilities $(+6.9 \%$ and $+22 \%)$, and other health impairments $(+13.2 \%$ and $+8.5 \%)$. This is in part explainable by lower comparative rates for students at the school classified with speech and language impairment $(-19.2 \%$ and $-18.5 \%)$.

\section{Figure 1}

\section{Enrollment of Special Education Students at the Online School by Classification}

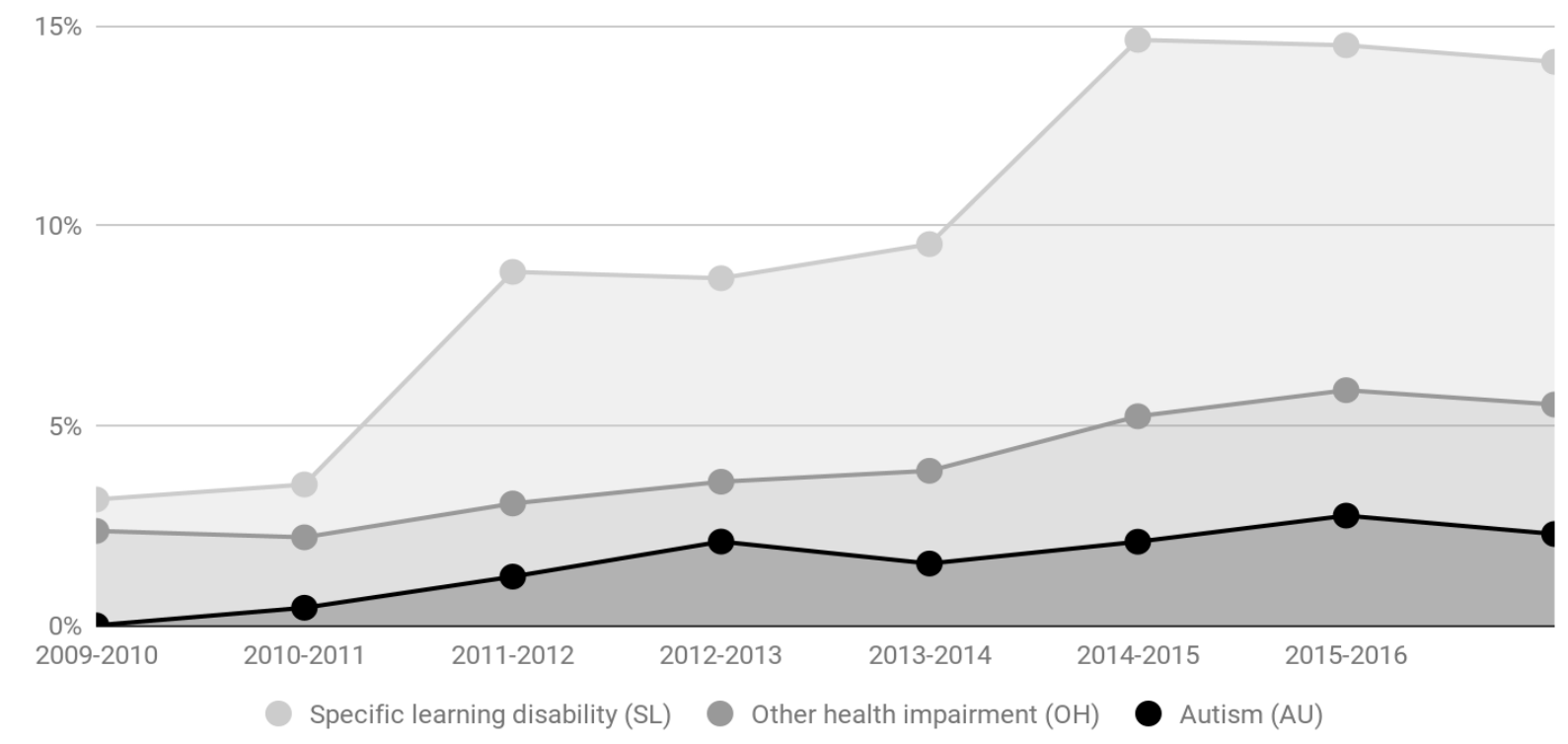

\section{Instrumentation and Rigor}

Built in the online survey platform Qualtrics, the cross-sectional survey for this study was developed over a two-year period that involved think-alouds with experts and potential participants, piloting, member-checking, colleague reviews, and other feedback mechanisms, because, as Lynch et al. (1986) argued, validity must be developed over time through diligence, attention to detail, and ongoing investment in the process. The final survey consisted of one 
general, open-ended question, seven Likert-scale type (ordinal) questions, and seven follow-up questions for the ordinal questions to allow participants to further explain their responses.

The initial, general open-ended question was worded as follows: "What is the main reason you decided to attend [this online school]?" Responses were analyzed qualitatively to determine common themes between responses as well as overarching themes. We elected to begin with this question because it most closely mirrored our guiding research question and allowed our respondents to express themselves freely with limited guidance from the survey prompts.

The seven items were then provided on a 4-point, non-neutral scaling, including options of "Strongly Disagree," "Disagree," "Agree," and "Strongly Agree." Results were recoded to numerical values of -1 (strongly disagree) to 1 (strongly agree). The seven questions included the following:

- Flexibility: "I chose to attend [this school] because of the flexible schedule."

- Online: "I chose to attend [this school] because it is online."

- Teacher availability: "I chose to attend [this school] because the teachers are available to help them."

- Curriculum: "I chose to attend [this school] because of the class lessons (What is taught in the classes.)"

- Parent as decision maker: "I chose to attend [this school] because my parents made me."

- Previous poor fit: "I chose to attend [this school] because our previous school was not a good fit."

- Laptop: "I chose to have my student attend [this school] because they got a laptop to use."

To ensure internal consistency, we calculated Cronbach's alpha on results. The resulting value was .71 (for students) and .7 (for parents), which is generally considered as "acceptable" in social science research situations (Bruin, 2006). Data were then inspected visually and descriptively, and question-to-question correlations were tested to determine relationships.

Following each scale item, a follow-up, open-ended question was also provided with unique wording to provide the participant with an opportunity to explain what their ordinal response meant, such as "Describe your experience with teacher availability." Responses to these questions were also analyzed qualitatively in light of developed themes from the initial question and in a manner that allowed identification of additional emergent themes.

\section{Data Collection}

The target population for the survey was the families of students with disabilities who attended the school for at least one year. To reduce coverage and sampling error, the survey was sent to all families that met the above criteria (Creswell, 2008).

The survey was administered using a three-phase procedure over a three-week period. The first emails were sent with a one-week response request, consistent with established school protocols. Non-responders were sent a second survey request the next week, and auto-texts were sent as well to reduce nonresponse error. IEP case managers, who communicated regularly with the students and parents, also provided verbal and text reminders to complete the survey. Each participant was a parent or a student at this school and was therefore accustomed to receiving and 
participating in a variety of surveys online. Surveys were sent out via email in the late spring, summer, and start of school, and were made available at student orientation. The student survey was distributed to 58 students with disabilities, and thirty students completed the survey, for a response rate of $52 \%$. The parent survey had an identical response rate, representing 29 responses from 56 parents. The response rate was deemed appropriate given that it was higher than response rates commonly achieved in email-based and mail-in survey designs (Patten, 2001). Several students and parents were invited to participate in follow-up interviews, described in a separate article (Tonks et al., 2020).

\section{Positionality}

The first author for this study was the principal of the online school, while the second and third authors were university researchers unaffiliated with the online school. As such, the lead researcher has been deeply involved in advocating for special education students and their educational well-being. While this level of involvement provided her with many insights and advantages in conducting this study, it also required that she carefully consider how her role and position affected how she carried out the research. This required sensitivity and recognition of limits to objectivity, but also served a vital purpose in the implementation of the study, because parents and students, who had developed strong, positive relationships with her over time, felt more comfortable sharing their experiences with her than they likely would have with an unknown third party.

An examination of "researcher subjectivity" (Maxwell, 2013, p. 124) or researcher bias in conjunction with the unassociated second author allowed the first author to thoroughly explore and reflect upon the issue, which is the best way to counteract bias. As the principal of the school, she had a vested interest in ensuring that the needs of families and students were being met, and her assumptions in conducting this research were influenced by prior surveys that included a $97 \%$ satisfaction rating with the school overall (Mountain Heights Academy, 2016). The second author, however, had no prior experience with the school and played the role of objective outsider to help ensure that the first author's assumptions were being challenged and that her interpretations were valid given the evidence provided.

By leveraging the benefits of both positions, we were able to capitalize on existing relationships with participants as well as insider knowledge of their experiences and the culture of the school while also benefiting from methodical doubt and outsider skepticism. We believe this counter-positioning of researchers helped to ensure a final study that was authentic and well positioned but also critical and analytic.

\section{Results}

The first question of the survey was open-ended and asked, "What is the main reason you decided to attend [this school]?" Responses were qualitatively coded, and two main themes emerged: (1) prior experiences and (2) learning environment.

\section{Prior Experiences}

Regarding prior experiences, $73 \%$ of students cited reasons related to (a) bullying, (b) teachers, (c) academics, and (d) disability/health. Five students indicated they had been bullied at their previous schools and were looking for an escape. These comments were very similar in nature: "I got bullied a lot," "kids were not kind to me," "a bully picked on me for no real reason," 
"to stop dealing with bullies," and "no bullying." Thus, multiple students indicated they chose the school to get away from negative interactions with others and to not be bullied while at school.

Four students referenced teachers as a reason for looking at the school. One student said, "The special ed department at my previous school was bad." Another student said they were looking for "great teachers," and two shared that they were specifically interested in getting more teacher help. Five students mentioned academic pieces of the education experience as motivating factors for selecting the school. One student shared that they "didn't like endless homework" while another said he had a hard time keeping his grades up. Two students referenced the school's academic reputation saying, "it is a good option" and "a great school." Three students had specific disability-related or health issues such as cerebral palsy, anxiety, and recovery post-surgery that prompted them to consider an online option. One student shared, "Anxiety and health issues made going to school difficult and I needed a school that could follow me home when I was recovering." Another said that learning at home helped her hips from being sore due to surgery.

\section{Learning Environment}

Regarding the learning environment, $93 \%$ of responses indicated that a change in the learning environment was a major driver for the students, in terms of when (meaning the flexibility or the schedule of when the student was learning), where (meaning the location the learning was taking place), and how (meaning how the instruction was delivered to the student online) learning occurred. Four students mentioned the timing of when they did their schoolwork with three students specifically mentioning having "more time" in general and another student explaining "I have more time to think." Another student indicated that he was a night owl and appreciated being able to complete his coursework in the evenings.

Six responses discussed the how of the learning environment in terms of level of comfort, location, fewer distractions, and attendance issues. For example, one student shared that he was more comfortable doing school online and another stated, "I can't be trusted to be in a school because I would ditch a lot." One student said he needed fewer distractions, while another said, "I was having a hard time at the school building and online was a lot easier for me." Five students included comments about the flexibility to go at their own pace and one mentioned being able to work in his pajamas and another on the ability to "do it anywhere." Two students said they just wanted a change or to try something new. Taken together, such comments reveal how complex affordances of the learning environment in terms of where, when, and how appeal to students in multiple ways and are necessary for finding learning experiences that work for them.

Collectively, such comments revealed that students were looking for a safer, more accessible option for learning, and the target school provided these opportunities by providing online learning experiences, devoted teachers, and flexibility.

After completing this first question, students answered each of the six Likert-scale questions and were prompted to explain their thoughts and feelings regarding each response. Comments were again coded qualitatively. Descriptive survey results of Likert-type questions revealed that responses were generally affirmative, with previous school not a good fit, online, teacher availability, and flexibility being the most affirmative and Laptop being the least (see Figure 2). 


\section{Figure 2}

Student Survey Response Distributions by Response Percent (left axis) and Averages and Variance (right axis)

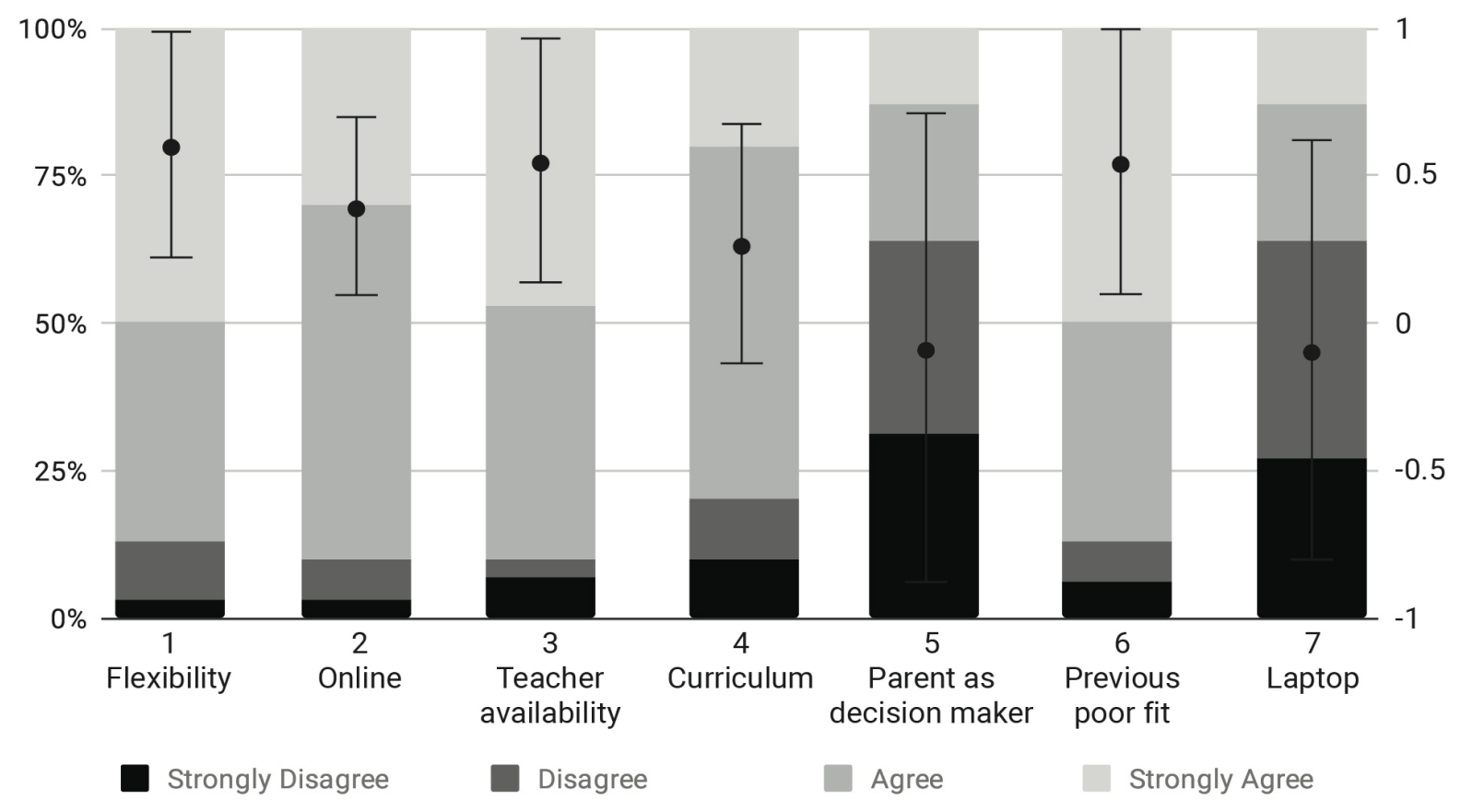

Magnitude of responses indicated that the three most important reasons for choosing the school were flexibility, poor fit at previous school, and online school. Examples of each of these are also provided in Table 2.

\section{Table 2}

Themes from Student Survey Open-Ended Comments

\begin{tabular}{|c|c|c|c|}
\hline \multicolumn{4}{|c|}{ Prior Experiences } \\
\hline Sub-Theme & Instances & $\%$ & Example Comment \\
\hline Bullying & 10 & $6.76 \%$ & "I got bullied a lot." \\
\hline Personnel & 13 & $8.78 \%$ & $\begin{array}{l}\text { "The special ed department at my previous } \\
\text { school was bad." }\end{array}$ \\
\hline Academics & 12 & $8.11 \%$ & "I didn’t like endless homework." \\
\hline $\begin{array}{l}\text { Disability and } \\
\text { Accommodations }\end{array}$ & 7 & $4.73 \%$ & $\begin{array}{l}\text { "They were not willing to help me with my } \\
\text { learning disabilities." }\end{array}$ \\
\hline Health Considerations & 10 & $6.76 \%$ & $\begin{array}{l}\text { "Anxiety and health issues made going to } \\
\text { school difficult, and I needed a school that } \\
\text { could follow me home when I was recovering." }\end{array}$ \\
\hline $\begin{array}{l}\text { When } \\
\text { (Schedule/Flexibility) }\end{array}$ & 26 & $17.57 \%$ & "I can see [course materials] whenever I want." \\
\hline Where (Location) & 29 & $19.59 \%$ & "I can do it anywhere." \\
\hline $\begin{array}{l}\text { How } \\
\text { (Online/Support) }\end{array}$ & 41 & $27.70 \%$ & "I have more time to think." \\
\hline
\end{tabular}




\section{Parent Responses}

To triangulate and enrich these results with other data, we also collected survey responses from parents $(n=29)$ and analyzed results in an identical manner. Likert-scale responses between the two groups were descriptively very similar, showing that the motivations for students shifting to the online school were generally shared with their parents (Fig. 3), with the greatest difference appearing on the Online question. Anecdotally, this difference seemed to emerge from some students not wanting to leave some positive social relationships they had at their previous schools.

\section{Figure 3}

Student Survey Response Distributions by Response Percent (left axis) and Averages and Variance (right axis)

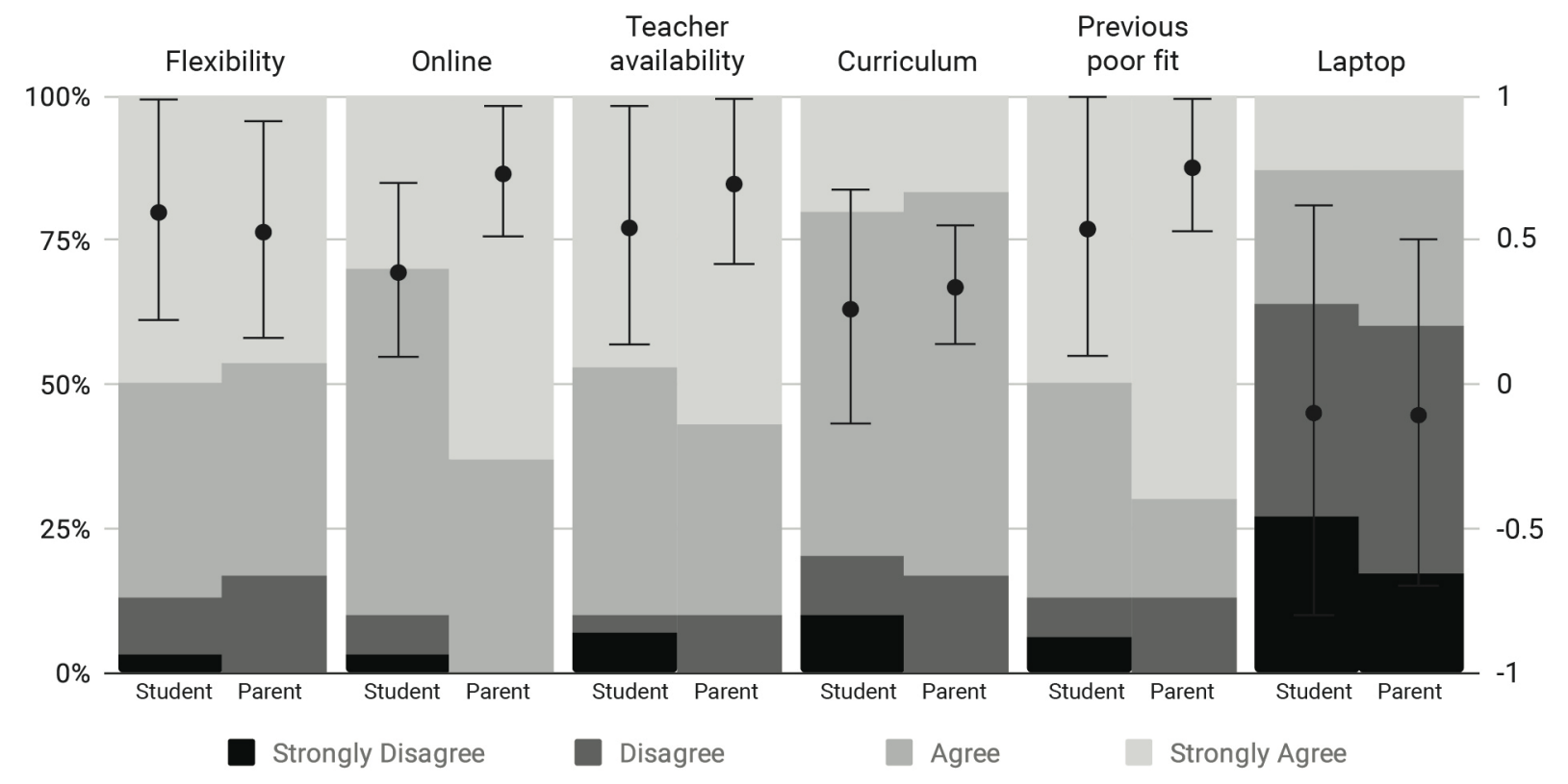

Thematic analysis of open-ended responses from parents corroborated thematic results from students but provided additional richness and insight into students' previous experiences. Table 3 includes example comments that show the depth of these issues along with their prevalence in parent responses.

In addition to corroborating themes from student responses, two new sub-themes emerged from parent responses that were previously absent: lack of support and self-determination. Lack of support was organized under the prior experiences theme and included instances where parents felt that school personnel were not working with them to address child needs. Three parents shared that there had been poor treatment of their children by their previous school's staff, which was communicated in terms of lacking (a) helpfulness, (b) caring, (c) trust, (d) responsiveness, and (e) understanding.

Self-determination, defined as the ability to make decisions for oneself, was organized under the learning environment theme and included instances where parents felt that their students had more of a voice and power to control their own learning. One parent said that her son chose the online school "to have more of a voice with his education," a sentiment echoed by a second parent. 
Table 3

Themes from Parent Survey Open-Ended Comments

\begin{tabular}{|c|c|c|c|}
\hline \multicolumn{4}{|c|}{ Prior Experiences } \\
\hline Sub-Theme & Instances & $\%$ & Example Comment \\
\hline Bullying & 23 & $9.83 \%$ & $\begin{array}{l}\text { The child "had been physically assaulted at } \\
\text { school several times." }\end{array}$ \\
\hline Personnel & 19 & $8.12 \%$ & $\begin{array}{l}\text { "Laws were broken, and then my child faced } \\
\text { harassment from the SpED Director and } \\
\text { Principal." }\end{array}$ \\
\hline Academics & 21 & $8.97 \%$ & $\begin{array}{l}\text { "He was struggling with reading so bad and it } \\
\text { was affecting EVERYTHING else." }\end{array}$ \\
\hline $\begin{array}{l}\text { Disability and } \\
\text { Accommodations }\end{array}$ & 22 & $9.40 \%$ & $\begin{array}{l}\text { "The teachers didn't understand her autism or } \\
\text { emotional needs." }\end{array}$ \\
\hline Health Considerations & 21 & $8.97 \%$ & $\begin{array}{l}\text { "Our fun-loving son had a mental breakdown } \\
\text { from the stress and he needed something } \\
\text { different. He was sick every day in anticipation } \\
\text { of school." }\end{array}$ \\
\hline Lack of Support & 18 & $7.69 \%$ & $\begin{array}{l}\text { The school had video evidence of the child } \\
\text { being kicked on the ground by a group of boys, } \\
\text { and "nothing was done." }\end{array}$ \\
\hline \multicolumn{4}{|c|}{ Learning Environment } \\
\hline Sub-Theme & Instances & $\%$ & Example Comment \\
\hline $\begin{array}{l}\text { When } \\
\text { (Schedule/Flexibility) }\end{array}$ & 19 & $8.12 \%$ & $\begin{array}{l}\text { The child benefits from "the ability to work on } \\
\text { school outside of school hours if needed." }\end{array}$ \\
\hline Where (Location) & 36 & $15.38 \%$ & $\begin{array}{l}\text { The child "has fewer distractions and a quiet } \\
\text { place to work." }\end{array}$ \\
\hline How (Online/Support) & 38 & $16.24 \%$ & "She can go at her own pace." \\
\hline Self-Determination & 17 & $7.26 \%$ & $\begin{array}{l}\text { The child chose the online school "to have } \\
\text { more of a voice with his education." }\end{array}$ \\
\hline
\end{tabular}

\section{Discussion and Conclusion}

All public schools, including online schools, have an obligation to meet the needs of their special education students. The number of special education students in online schools is increasing, yet relatively few studies exist that give voice to and shed light on special education students' experiences in online schools. In this study, the authors analyzed survey responses from special education students at an online charter school and survey responses of their parents to understand why students had chosen the school and how it was working for them. It is possible that there was selection bias among those who chose to participate. The survey was not sent to students who had chosen to leave the school. As with all smaller studies, the findings may not be generalizable. More research is needed to understand student experiences in and motivation to attend online schools. Despite the limitations of the study, the authors believe the findings are valuable for educators, educational administrators, policy makers, and instructional designers. 
First, it is clear from these results that students and their parents were drawn to this online school for a number of reasons stemming from both prior experiences and affordances of the learning environment, but those who found success at the school emphasized relationships with school personnel as being paramount for student success. Previous studies have indicated that students, parents, and teachers chose online charter schools both to flee negative environments and to take advantage of online schools' flexibility and convenience (Ahn, 2011; Beck et al., 2014; Hasler-Waters et al., 2014; Macy et al., 2018). Similarly, our survey results showed that students had left schools where they had experienced bullying, struggled academically, lacked adequate support, and did not receive legally mandated accommodations, and chose instead the online school because of its flexibility, teacher availability, and support. Given families' negative prior experiences, an online school-with its accompanying decreased social interaction and physical access to bullies - represented a promising alternative to families trying to provide for their children's needs.

But though such withdrawal from abusive or negligent relationships in brick-and-mortar settings is understandable, these students and their parents further sought, expected, and appreciated focused support, high levels of teacher availability, and flexibility for their individual circumstances, and many of them had tried other online alternatives before finding this one that worked for them. This is noteworthy because many pushes for online schooling in the U.S. today seem to be primarily motivated by interest in decreasing costs and student-teacher interaction, often resulting in higher student-teacher ratios (Burdette et al., 2013; Hasler-Waters et al., 2014; Molnar et al., 2019). Yet, in this school, teacher availability and responsiveness were often cited in survey responses as the most valuable school elements, making it "an answer to a prayer" for many parents. The school in this study had a relatively low student-teacher ratio of 1:19.5, which is much lower than many online schools and also many of their brick-and-mortar counterparts, and teachers were specifically hired, trained, and encouraged to be continually engaged in outreach and support efforts to their students and their families.

The implications for practice are that for online schools to successfully meet the needs of special education students, these schools must not only provide a safe, flexible learning environment, but also provide teachers who are capable, available, and supportive. Teachers need training both in teaching online and in implementing IEPs. Online teaching requires a different skill set from in-person teaching (Ahn, 2011; Pulham \& Graham, 2018), yet most states lack endorsements or certification in online teaching (Basham et al., 2015). States should offer certification and endorsements in online teaching. Schools should implement appropriate studentteacher ratios, teacher training, and support. Teachers must understand how to meet students' special needs online, and their legal responsibility to do so (Cavendish et al., 2020; Kozleski, 2020; Macy et al., 2018; Rice \& Carter, 2015).

Second, curriculum matters. To meet diverse needs, instructional materials should be designed according to universal design principles (Betts et al., 2013; Macy et al., 2018; Singleton et al., 2019). In this study, students were generally favorable toward the curriculum but also mentioned that not all materials were created equal. Though this may seem obvious, it is an important point to emphasize, because most online schools rely entirely upon third parties for curriculum delivery (Crouse et al., 2016; Greer et al., 2014; Rice \& Carter, 2016). Though using commercial curriculum by itself may not be predictive of overall curriculum quality, it can be very limiting for teachers when seeking to teach students with disabilities and other special needs, and 
it also limits the school's ability to engage in developmental evaluation and continuous improvement practices.

Though some areas of the curriculum at the target school may be in need of revision and improvement, it at least can be improved upon and adapted to specific learner needs because it is based on open educational resources (OER), which give teachers and other school personnel the power and ability to engage in such an improvement process (Geith \& Vignare, 2008). This is not so for online schools that rely upon proprietary curricula, which teachers cannot edit, adapt, update, or improve upon and over which teachers and schools have limited control. As Basham et al. (2015) noted, "the flexibility of digital learning materials, when combined with appropriately designed online delivery systems and instruction, can address the variable learning needs of elementary and secondary students with disabilities in ways difficult or impossible to otherwise achieve" (p. 12). By taking approaches that emphasize the teacher's role as a curriculum developer, adapter, and remixer, online schools can both assist in re-professionalizing teachers as content experts and empower them to engage in the types of intense customization necessary to meet the needs of diverse learners (Kimmons, 2016). The implication for online schools is that to meet the needs of students with special needs, schools must use high-quality, accessible curricula, and that may mean creating or adapting curricula.

And third, it is clear from this analysis that the pull toward online education for these students and their parents had little to do with the technologies themselves. Most cared little that a laptop was provided, or the laptop was seen as merely a perk or an enabling mechanism for the solution that they were truly looking for. The implication is that online schools must provide much more than laptops to their students. Rather, as Seymour Papert argued against technocentrism nearly 30 years ago, we should not think about technology as "having an effect" on education but as an "opportunity offered us ... to rethink what learning is all about, to rethink education" (1990, para. 5).

For the families in our study, their prior school experiences were dissatisfactory. Had they enrolled in an online school that merely replicated brick-and-mortar settings or (worse) that assumed that a technology, program, or canned curriculum itself would somehow meet their needs, then they may have been further frustrated. Instead, in the online school that served as the setting for this study, families found a learning approach that was safe, customized, supportive, caring, and self-determined. As one parent later explained,

[my child now] gets the kind of attention that I think every kid should be able to get in school. It's a shame the other schools can't deliver it because they're overburdened and can't figure out how to make it happen. 


\section{References}

Ahn, J. (2011). Policy, technology, and practice in cyber charter schools: Framing the issues. Teachers College Record, 113(1), 1-26.

Basham, J.D., Stahl, S., Ortiz, K., Rice, M.F., \& Smith, S. (2015). Equity matters: Digital \& online learning for students with disabilities. Lawrence, KS: Center on Online Learning and Students with Disabilities. https://kuscholarworks.ku.edu/handle/1808/22555

Barbour, M. K., Miron, G., \& Huerta, L. (2017). Virtual schools in the U.S.: Case studies of policy, performance, and research evidence. Lansing, MI: Michigan Virtual University. http://media.mivu.org/institute/pdf/VSCase-17.pdf

Barbour, M. K., \& Reeves, T. C. (2009). The reality of virtual schools: A review of the literature. Computers \& Education, 52(2), 402-416. https://doi.org/10.1016/j.compedu.2008.09.009

Baule, S. M. (2020). Evaluating the accessibility of special education cooperative websites for individuals with disabilities. TechTrends, 64(1), 50-56.

Beck, D., Egalite, A., \& Maranto, R. (2014). Why they choose and how it goes: Comparing special education and general education cyber student perceptions. Computers \& Education, 76, 70-79.

Betts, K., Cohen, A. H., Veit, D. P., Alphin Jr, H. C., Broadus, C., \& Allen, D. (2013). Strategies to increase online student success for students with disabilities. Journal of Asynchronous Learning Networks, 17(3), 49-64.

Bruin, J. 2006. Newtest: command to compute new test. UCLA: Statistical Consulting Group. https://stats.idre.ucla.edu/stata/ado/analysis/Burdette, P. J., Greer, D. L., \& Woods, K. L. (2013). K-12 online learning and students with disabilities: Perspectives from state special education directors. Journal of Asynchronous Learning Networks, 17(3), 65-72.

Carnahan, C., \& Fulton, L. (2013). Virtually forgotten: Special education students in cyber schools. TechTrends, 57(4), 46-52.

Cavanaugh, C. S., Barbour, M. K., \& Clark, T. (2009). Research and practice in K-12 online learning: A review of open access literature. International Review of Research in Open and Distance Learning, 10. 2-13.

Cavanaugh, C., Gillan, K. J., Kromrey, J., Hess, M., \& Blomeyer, R. (2004). The effects of distance education on K-12 student outcomes: A meta-analysis. Learning Point Associates/North Central Regional Educational Laboratory (NCREL). http://faculty.education.ufl.edu/cathycavanaugh/docs/EffectsDLonK-12Students1.pdf

Cavendish, W., Morris, C. T., Chapman, L. A., Ocasio-Stoutenburg, L., \& Kibler, K. (2020). Teacher perceptions of implementation practices to support secondary students in special 
education. Preventing School Failure: Alternative Education for Children and Youth, 64(1), 19-27.

Clifford, S. E. (2018). The Implementation of the Individuals with Disabilities Education Act in a Virtual Public Charter School (Publication No. 2449) [Doctoral dissertation, University of New Orleans]. Scholarworks. https://scholarworks.uno.edu/td/2449

Creswell, J. W. (2008). Educational research: planning, conducting and evaluating quantitative and qualitative research (pp. 387-396, 552-566). Upper Saddle River, NJ: Pearson.

Crouse, T. M., Rice, M. F., \& Mellard, D. F. (2016). "How did I survive?" Online teachers describe learning to teach students with disabilities. Lawrence, KS: Center on Online Instruction and Students with Disabilities, University of Kansas. https://kuscholarworks.ku.edu/handle/1808/22567

Digital Learning Collaborative. (2020). Snapshot 2020: A review of K-12 online, blended, and digital learning. https://www.digitallearningcollab.com

de los Arcos, B., Farrow, R., Pitt, R., Weller, M., \& McAndrew, P. (2016). Personalising learning through adaptation: Evidence from a global survey of K-12 teachers' perceptions of their use of open educational resources. Journal of Online Learning Research, 2(1), $23-40$.

Employee Handbook and Policy Guide [Google Document]. (2017). West Jordan: Mountain Heights Academy.

Fernandez, H., Ferdig, R. E., Thompson, L. A., Schottke, K., \& Black, E. W. (2016). Students with special health care needs in K-12 virtual schools. Educational Technology \& Society, 19(1), 67-75.

Ferdig, R. E., \& Kennedy, K. (2013). Handbook of Blended Learning. 107-134 http://press.etc.cmu.edu/files/Handbook-Blended-Learning_Ferdig-Kennedyetal_web.pdf

Geith, C., \& Vignare, K. (2008). Access to Education with Online Learning and Open Educational Resources: Can They Close the Gap? Journal of Asynchronous Learning Networks, 12(1), 105-126.

Gemin, B., \& Pape, L. (2016). Keeping Pace Annual Report (Rep.). https://static1.squarespace.com/static/59381b9a17bffc68bf625df4/t/593efc779f745684e6 ccf4d8/1497300100709/EEG_KP2016-web.pdf

Greer, D., Rowland, A. L., \& Smith, S. J. (2014). Critical considerations for teaching students with disabilities in online environments. Teaching Exceptional Children, 46(5), 79-91. doi:10.1177/0040059914528105 
Harvey, D., Greer, D., Basham, J., \& Hu, B. (2014). From the student perspective: Experiences of middle and high school students in online learning. American Journal of Distance Education, 28(1), 14-26.

Hasler-Waters, L., Barbour, M.-K., \& Menchaca, M.-P. (2014). The nature of online charter schools: Evolution and emerging concerns. Educational Technology \& Society, 17(4), 379-389.

Hassel, B. C., Terrell, M. G., \& Public Impact (2001). How can virtual schools be a vibrant part of meeting the choice provisions of the no child left behind act? Leadership, 1-13.

Hawkins, A., Barbour, M. K., \& Graham, C. R. (2012). "Everybody is their own island": Teacher disconnection in a virtual school. The International Review of Research in Open and Distributed Learning, 13(2), 124. https://doi.org/10.19173/irrodl.v13i2.967

Kimmons, R. (2016). Expansive openness in teacher practice. Teachers College Record, 118(9), $1-34$.

Kimmons, R., \& Smith, J. (2019). Accessibility in mind? A nationwide study of K-12 websites in the U.S. First Monday, 24(2). doi:10.5210/fm.v24i2.9183

Kozleski, E.B. (2020). NEPC Review: "Special Education and Distance Learning: Supporting Students Through the Pandemic." Boulder, CO: National Education Policy Center. https://nepc.colorado.edu/thinktank/special-education-pandemic

Lynch, J. G., Brinberg, D., \& McGrath, J. E. (1986). Validity and the Research Process. Journal of Marketing Research, 23(4), 394. https://doi.org/10.2307/3151816

Macy, M., Macy, R., \& Shaw, M. E. (2018). Bringing the ivory tower into students' homes: Promoting accessibility in online courses. Ubiquitous Learning: An International Journal, 11(1). https://doi.org/10.18848/1835-9795/CGP/v11i01/13-21.

Mason-Williams, L., Bettini, E., Peyton, D., Harvey, A., Rosenberg, M., \& Sindelar, P. T. (2020). Rethinking shortages in special education: Making good on the promise of an equal opportunity for students with disabilities. Teacher Education and Special Education, 43(1), 45-62.

Maxwell, J. A. (2013). Qualitative Research Design. Thousand Oaks, CA: Sage.

Molnar, A. (Ed.); Huerta, L., Shafer, S. R., Barbour, M.K., Miron, G., Gulosino, C. (2015). Virtual schools in the U.S.2015: Politics, performance, policy, and research evidence. Boulder, CO: National Education Policy Center. http://nepc.colorado.edu/publication/virtual-schools-annual-2015 
Molnar, A., Miron, G., Elgeberi, N., Barbour, M.K., Huerta, L., Shafer, S.R., Rice, J.K. (2019). Virtual Schools in the U.S. 2019. Boulder, CO: National Education Policy Center. http://nepc.colorado.edu/publication/virtual-schools-annual-2019

National Center for Education Statistics. (2017). Table 204.30 Children 3 to 21 years old served under Individuals with Disabilities Education Act (IDEA), Part B, by type of disability: Selected years, 1976-77 through 2015-16. https://nces.ed.gov/programs/digest/d17/tables/dt17_204.30.asp

Ortiz, K., Rice, M., Smith, S., \& Mellard, D. F. (2017). Roles and responsibilities of parents of online school students with disabilities. Lawrence, KS: Center on Online Learning and Students with Disabilities, University of Kansas. https://kuscholarworks.ku.edu/handle/1808/22555

Papert, S. (1990). A critique of technocentrism in thinking about the school of the future. M.I.T. Media Lab Epistemology and Learning Memo, 2. http://www.papert.org/articles/ACritiqueofTechnocentrism.html

Patten, M. (2001). Questionnaire research: A practical guide. Glendale, CA: Pyrczak Publishing. Peyton, D. J., Acosta, K., Harvey, A., Pua, D. J., Sindelar, P. T., MasonWilliams, L., ... \& Crews, E. (2020). Special education teacher shortage: Differences between high and low shortage states. Teacher Education and Special Education, https://doi.org/10.1177/0888406420906618 .

Pulham, E., \& Graham, C. R. (2018). Comparing K-12 online and blended teaching competencies: A literature review. Distance Education, 39(3), 411-432.

Rice, M. F., \& Carter Jr, R. A. (2015). "When we talk about compliance, it's because we lived it": Online educators' roles in supporting students with disabilities. Online Learning, 19(5), 18-36.

Rice, M., \& Carter, Jr., R. (2016). Online teacher work to support self-regulation of learning in students with disabilities at a fully online state virtual school. Online Learning, 20(4). https://doi.org/10.24059/olj.v20i4.1054

Schuck, R., \& Lambert, R. (2020, September 10). “Am I doing enough?” Special educators” experiences with emergency remote teaching in spring 2020. OSF Preprints. https://doi.org/10.31219/osf.io/3c4gs

Singleton, K., Evmenova, A., Kinas Jerome, M., \& Clark, K. (2019). Integrating UDL strategies into the online course development process: Instructional designers' perspectives. Online Learning, 23(1), 206-235. https://doi.org/10.24059/olj.v23i1.1407

Sorensen, T. (2019). Special education in Idaho virtual schools: An analysis of the efficacy of service delivery (Publication No. 13883544) [Doctoral dissertation, Northwest Nazarene University]. ProQuest Dissertations Publishing. 
Tonks, D., Kimmons, R., \& Mason, S. L. (2020). Mattering is motivating: Special education students' experiences with an online charter school. Journal of Online Learning Research, 6(3), 221-244. https://www.learntechlib.org/primary/p/217275/

UTREx Clearinghouse Report (Rep.). (2018). Salt Lake City, UT: Utah State Board of Education. https://www.schools.utah.gov/informationtechnology/utrex

Vasquez III, E., \& Serianni, B. A. (2012). Research and practice in distance education for K-12 students with disabilities. Rural Special Education Quarterly, 31(4), 33-42.

Woodfine, B., Nunes, M. B., \& Wright, D. (2008). Text-based synchronous e-learning and dyslexia: Not necessarily the perfect match! Computers \& Education, 50(3), 703-717. https://doi.org/10.1016/j.compedu.2006.08.010

Woodworth, J. L., Raymond, M. E., Chirbas, K., Gonzalez, M., Negassi, Y., Snow, W., \& Van Donge, C. (2015). Online charter school study 2015. Center for Research on Educational Outcomes. https://credo.stanford.edu/pdfs/Online\%20Charter\% 20Study20Final.pdf 